\title{
Konfigurasi Batuan Dasar Daerah Sekitar Rencana Pembangunan Reaktor Daya Eksperimental Serpong
}

\author{
Hadi Suntoko', Marjiyono², Imam Setiadi' ${ }^{2}$, Heni Susiati' ${ }^{1}$, Yuni $\mathbf{W}^{1}$, Theo Alvin $\mathbf{R}^{1}$ \\ 1, Pusat Kajian Sistem Energi Nuklir, BATAN, Jl Kuningan Barat Mampang Prapatan Jaksel, email:hadi_suntoko@batan.go.id \\ 2.Pusat Survei Geologi, Badan Geologi, Kementerian ESDM. Bandung 40122, email: marjiyono@grdc.esdm.go.id
}

\begin{tabular}{l} 
INFORMASI ARTIKEL \\
\hline Riwayat Artikel: \\
Diterima: \\
16 Juli 2020 \\
Diterima dalam bentuk revisi: \\
24 Agustus 2020 \\
Disetujui: \\
31 Agustus 2020
\end{tabular}

Kata kunci:

Mikrotremor single station

Array

Frekuensi Resonan

Kecepatan Gelombang Geser

\begin{abstract}
ABSTRAK
KONFIGURASI BATUAN DASAR DAERAH SEKITAR RENCANA PEMBANGUNAN REAKTOR DAYA EKSPERIMENTAL SERPONG. Proses pemilihan tapak diperlukan informasi geologi bawah permukaan yang merupakan aspek penting terutama berkaitan dengan daya dukung lapisan/tanah. Informasi kondisi batuan dasar yang ditunjukkan oleh nilai kecepatan gelombang geser diperlukan untuk penempatan pondasi bangunan. Penerapan kombinasi metode mikrotremor array dan single station adalah untuk mengetahui kedalaman batuan dasar lebih rinci secara lateral berdasarkan nilai frekuensi resonan yang dilakukan untuk memodelkan kondisi bawah permukaan daerah Puspiptek Serpong. Tujuan penelitian adalah memodelkan batuan bawah permukaan di tapak RDE berdasarkan profil kecepatan gelombang geser secara vertikal dengan 10 titik ukur. Pengolahan data menggunakan perangkat lunak Geopsy dan validasi data mikrotremor array menggunakan data N-SPT di tapak. Hasil perhitungan menunjukkan hingga kedalaman $64 \mathrm{~m}$ diperoleh model dua lapis batuan dengan nilai kecepatan bervariasi secara lateral maupun vertikal. Lapisan permukaan mempunyai kisaran nilai kecepatan gelombang geser antara $150 \mathrm{~m} /$ detik hingga 360 $\mathrm{m} /$ detik pada kedalaman sekitar $19 \mathrm{~m}$, sedangkan lapis kedua yang dianggap sebagai batuan dasar di daerah ini mempunyai kecepatan gelombang geser berkisar antara $365 \mathrm{~m} /$ detik hingga $900 \mathrm{~m} /$ detik pada kedalaman sekitar $60 \mathrm{~m}$.
\end{abstract}

\begin{abstract}
BEDROCK CONFIGURATION OF SERPONG EXPERIMENTAL POWER REACTOR SITE PLAN AREA.

Site selection process required subsurface geological information which closely related to characteristic of soil capacity. The condition of bedrock which indicated by shear wave velocity is needed for placement of the building foundation. The application of combined array and single station microtremor was intended to detect the bedrock depth laterally based on resonant frequency value which is performed on subsurface geological modeling arround Puspiptek Serpong area. The objective of this paper was to establish the subsurface model based on shear wave velocity profile using 10 point of measurement in RDE site area. Data processing was performed using Geopsy and the microtremor array was validated using N-SPT in RDE site. The result of modelling showed that down to $64 \mathrm{~m}$ depth, there are two layers lithologies, with shear wave velocity variation laterally as well as vertically. The surface layer had shear wave velocity in the range of $150 \mathrm{~m} / \mathrm{s}$ to $360 \mathrm{~m} / \mathrm{s}$ at a depth of about $19 \mathrm{~m}$, while second layer which considered as the berdorck, had shear wave velocity in the range of $365 \mathrm{~m} / \mathrm{s}$ to $900 \mathrm{~m} / \mathrm{s}$ at a depth of about $60 \mathrm{~m}$.

Keywords: single station microtremor, array, resonant frequency, shear wave velocity.
\end{abstract}

\section{PENDAHULUAN}

Badan Tenaga Nuklir Nasional (BATAN) sedang menyiapkan kegiatan khusus pada pembangunan pembangkit tenaga listrik untuk memenuhi proyeksi kebutuhan tenaga listrik sebesar 35 ribu megawatt pada 5 tahun mendatang (2019-2024), baik pembangkit listrik tenaga air, gas, batubara, panas bumi dan sebagainya. Menilik pembangkitan energi di negara-negara maju, energi nuklir menjadi

*Penulis korespondensi.

E-mail: hadisuntoko@batan.go.id salah satu sumber energi utama untuk memenuhi kebutuhan energi. Potensi bahan galian nuklir di Indonesia cukup melimpah dengan cadangan spekulatif uranium di Indonesia sekitar 59.200 ton (2014) atau setara dengan 6,5 GWe dan thorium sekitar 1500 ton atau setara dengan 1850 Mwe[1]. Hingga saat ini energi nuklir di Indonesia belum dimanfaatkan sebagai energi listrik. BATAN baru-baru ini merintis pilot project pembangunan pembangkit listrik tenaga nuklir (PLTN), yaitu di kompleks Puspiptek Serpong 
berupa reaktor daya eksperimental (RDE) seperti terlihat pada Gambar 1.

Sehubungan dengan rencana pembangunan RDE tersebut, maka informasi kondisi bawah permukaan khususnya batuan dasar di wilayah ini perlu dipetakan. Ada banyak cara untuk memetakan batuan dasar di suatu wilayah, diantaranya dengan pemboran, NSPT, seismik refraksi, MASW dan sebagainya, namun demikian metode-metode tersebut mahal dan menyita waktu.

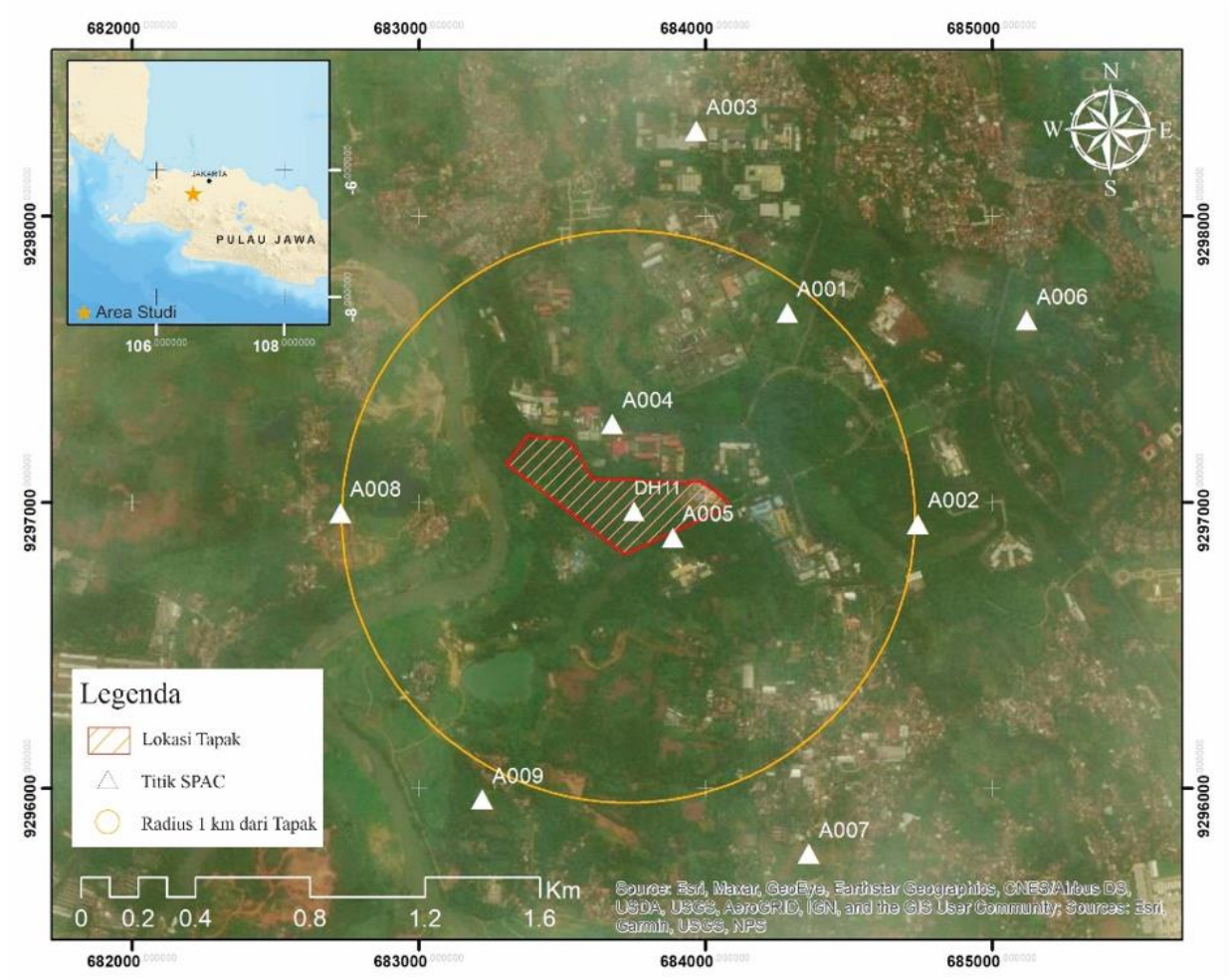

Gambar 1. Lokasi pilot project RDE (garis merah) dan titik Pengukuran SPAC

Metode mikrotremor menawarkan metode alternatif yang murah dan cepat serta praktis dalam penerapannya. Metode ini pada prinsipnya merupakan metode seismik pasif yang bersumber dari ambient noise. Dalam dua dasawarsa terakhir perkembangan metode ini cukup pesat terutama sejak algoritma HVSR (horizontal to vertical spectral ratio) digunakan oleh Nakamura[2] untuk mempelajari karakteristik geologi permukaan. Hingga saat ini metode mikrotremor sudah banyak diterapkan dalam bidang migas, geologi teknik, rekayasa bangunan dan kebencanaan. Dalam penerapannya di dalam bidang geologi teknik, metode ini digunakan untuk memodelkan struktur bawah permukaan berupa struktur model kecepatan gelombang geser.

Suntoko dan Sriyana [3], telah melakukan investigasi keberadaan batuan dasar (Vs>750 m/detik) di kedalaman 391 meter berdasarkan data mikrotremor array dengan metode SPAC menggunakan perangkat lunak Seisimager. Penelitian tersebut dilakukan untuk mendukung analisis probabilistik bahaya kegempaan di tapak RDE. Namun demikian, detail klasifikasi batuan bawah permukaan diperlukan investigasi yang lebih lengkap. Marjiyono dkk [4] telah melakukan pengukuran mikrotremor array sembilan titik di tapak RDE dan menyimpulkan bahwa sampai dengan kedalaman 30 meter terdapat dua lapis litologi yang mempunyai range Vs 160-253 $\mathrm{m} /$ detik untuk lapisan pertama dan 493-900 m/detik untuk lapisan kedua. Sedangkan Iswanto dkk [5], menggunakan 1 titik ukur tambahan untuk mendapatkan profil gelombang Vs di tapak RDE.

Tujuan penelitian ini adalah untuk memodelkan batuan bawah permukaan tapak RDE termasuk penentuan batuan dasar dengan mengolah ulang data mikrotremor array menggunakan 10 titik ukur dan menggunakan 
parameter model inversi yang lebih akurat dengan validasi parameter menggunakan hasil N-SPT di tapak RDE.

\section{GEOLOGI DAERAH PENELITIAN}

Berdasarkan Peta Geologi Lembar Jakarta dan Kepulauan Seribu skala 1 : 100.000[6] daerah Serpong dan sekitarnya ditempati oleh Formasi Bojongmanik, Formasi Genteng, Formasi Serpong dan endapan kipas aluvial serta endapan alluvial, Gambar 2.

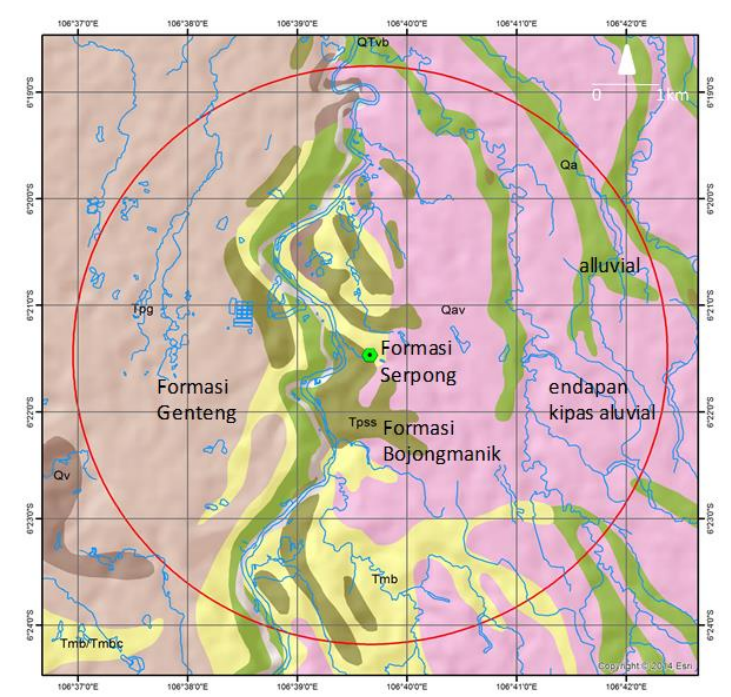

Gambar 2. Peta geologi daerah Serpong dan sekitarnya (warna lingkaran hijau tapak RDE)

Formasi Bojongmanik yang ditemukan di daerah ini berupa batupasir gampingan berwarna abu-abu kehijauan, berbutir halus sampai sedang dan terpilah baik. Batupasir gampingan ini tersingkap di sepanjang Sungai Cisadane di sekitar Serpong. Di beberapa tempat ditemukan berselingan dengan batulempung berwarna abu-abu kebiruan dan sisipan batugamping masif berwarna abu-abu kekuningan, mengandung fosil moluska dan koral. Batuan ini diperkirakan berumur Miosen Tengah.

Batuan Formasi Genteng di daerah Serpong umumnya ditemukan di sebelah barat Sungai Cisadane berupa batupasir tufan berwarna abu-abu kebiruan dengan ukuran butir sedang hingga kasar. Batupasir ini mengandung glaukonit, kuarsa dan kayu terkersikkan. Menurut Turkandi, dkk.[6] secara keseluruhan Formasi Genteng terdiri atas tuf batuapung, batupasir tufan, breksi, andesit, konglomerat dan sisipan lempung tufaan. Berdasarkan kedudukan Formasi tersebut, posisinya menindih secara tidak selaras terhadap Formasi Bojongmanik. Formasi Genteng ini diperkirakan berumur Pliosen Awal hingga Pliosen Tengah.

Formasi Serpong yang ditemukan di daerah ini berupa konglomerat berwarna coklat muda hingga hitam kebiruan dengan fragmen andesit, basalt, batugamping, rijang dan fosil kayu, matrik berupa pasir hitam dengan kemas terbuka dan terpilah sedang. Di beberapa tempat batuan Formasi Serpong ditemukan berupa perselingan konglomerat, batupasir, batulanau, batulempung, konglomerat batuapung dan tuf batuapung. Batuan ini menindih secara tidak selaras terhadap Formasi Bojongmanik dan Genteng. Formasi Serpong ini diperkirakan berumur Pliosen Akhir. Bila ditinjau sebaran batuan ini yang berada di sekitar sungai serta bentuk struktur sedimennya, diperkirakan batuan ini merupakan endapan sungai.

Satuan kipas aluvial di daerah Serpong dijumpai berupa tufa halus berlapis, tufa pasiran berselingan dengan tufa konglomeratan. Batuan ini diduga berumur Plistosen hingga Holosen. Adapun satuan endapan aluvial dijumpai di sekitar Sungai Cisadane dan anak-anak sungainya berupa lempung, lanau, pasir, kerikil, kerakal dan bongkah batuan beku.

\section{METODOLOGI}

Penelitian menggunakan metode mikrotremor cukup efektif untuk memodelkan kondisi geologi bawah permukaan [7-9]. Secara umum metode mikrotremor dapat dibedakan menjadi dua model, yaitu metode mikrotremor array dan mikrotremor single station. Metode mikrotremor array adalah pengukuran ambient noise dengan menggunakan beberapa seismometer secara simultan dengan konfigurasi tertentu, sedangkan mikrotremor single station dengan menggunakan sebuah seismometer tiga komponen (3D). Kedua metode ini dapat diaplikasikan secara sendiri-sendiri maupun dengan kombinasi [10, 11]. Dalam penelitian ini, analisis konfigurasi batuan dasar dilakukan dengan metode mikrotremor array. 
Konfigurasi pengukuran yang dilakukan oleh Marjiono dkk dilakukan dengan menggunakan metode triangle nested (Gambar 3), sedangkan pengukuran yang dilakukan oleh Iswanto dkk menggunakan konfigurasi equilateral triangle shape (Gambar 4).

Pengolahan ulang dilakukan untuk meningkatkan akurasi informasi kecepatan gelombang sekunder dengan perangkat lunak Geopsy. Fokus parameter model inversi adalah pada kecepatan gelombang S dan kedalaman. Rentang nilai kecepatan gelombang $\mathrm{S}$ dan kedalaman dibuat lebar agar mengakomodasi segala kemungkinan model kecepatan. Input parameter model kecepatan gelombang S pada lapisan pertama dan kedua sebesar 100 - 1500 $\mathrm{m} / \mathrm{s}$ dengan kedalaman 1-70m sedangkan rentang kecepatan gelombang $\mathrm{P}$, densitas, serta Poisson's ratio menggunakan nilai default dari perangkat lunak. Parameter tuning iterasi yang digunakan sebanyak 100 .
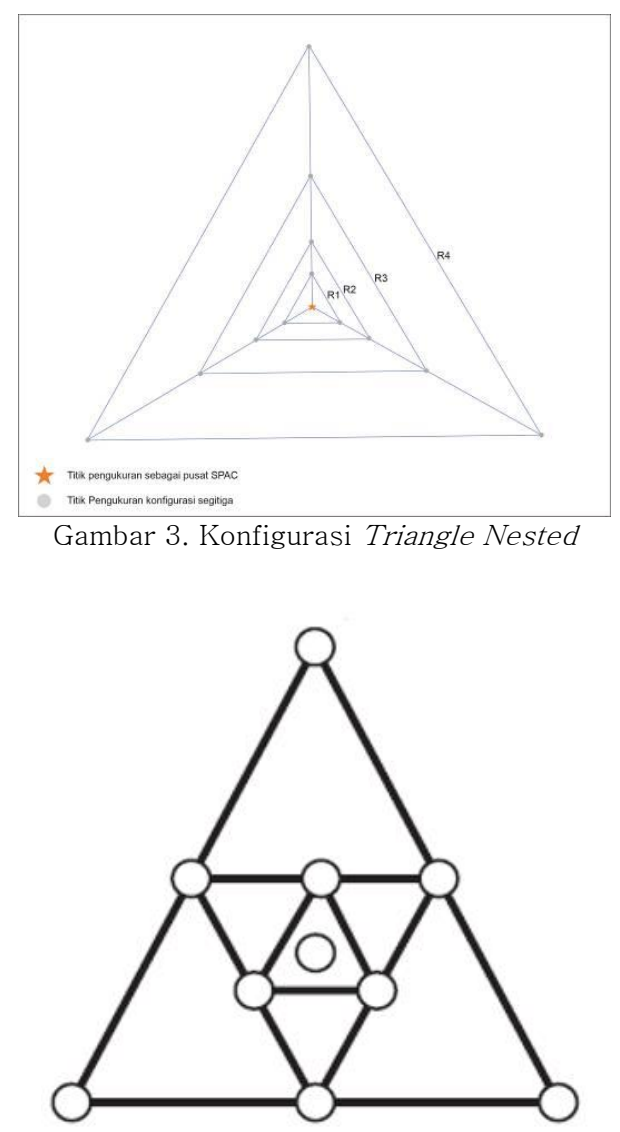

Gambar 4. Konfigurasi Equilateral Triangle Shape

1D dilakukan dengan metode spatial autocorelation (SPAC) berdasarkan pada formula Aki[12] yang secara matematik dinyatakan sebagai : $\rho(r, \omega)=J_{0}\left(\frac{\omega}{c(\omega)} r\right)$

Dimana:

$\rho \quad$ : koefisien korelasi antara dua seismometer

$\mathrm{r} \quad: \quad$ jarak antar seismometer

$\omega \quad$ : frekuensi anguler

$\mathrm{J}_{0} \quad$ : fungsi Bessel jenis pertama orde nol

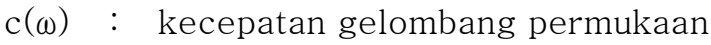

Nilai $\rho(r, \omega)$ dapat dihitung dari hasil pengukuran sehingga dengan menggunakan persamaan (1) nilai kecepatan gelombang permukaan $\mathrm{c}(\omega)$ yang merupakan fungsi frekuensi anguler dapat dihitung. Selanjutnya besaran kecepatan gelombang geser dapat diinversi dari fungsi kecepatan gelombang permukaan $c(\omega)$. Hasil inversi berupa struktur kecepatan gelombang geser satu dimensi (1D), yang datanya disusun berdasarkan intepretasi mikrotremor array (Gambar 1, lokasi titik pengukuran SPAC).

\section{HASIL DAN PEMBAHASAN}

Data hasil pengukuran mikrotremor dan informasi geologi permukaan selanjutnya dilakukan pengolahan yang menghasilkan model kecepatan gelombang geser dari 2 lapisan. Lapisan pertama atau lapisan teratas diiterpretasikan sebagai lapisan soil hasil pelapukan batuan berupa material lempungan yang diperkirakan terdapat di kedalaman sekitar 0-20m. Adapun lapisan kedua yang dipertimbangkan sebagai lapisan batuan di daerah penelitian. Batas dari lapisan tersebut dilihat dari dari perubahan nilai kecepatan gelombang geser yang tajam terhadap lapisan permukaan. Kedalaman lapisan kedua diperkirakan > 20m. Model kecepatan gelombang geser hasil inversi data mikrotremor array di 10 titik ukur ditampilkan pada Gambar 5. Kecepatan gelombang geser lapisan pemukaan di 10 titik ukur bervariasi dengan kisaran $150 \mathrm{~m} /$ detik hingga 350 $\mathrm{m} /$ detik. Berdasarkan data pemboran di beberapa titik di RDE lapisan permukaan tersebut rata rata berupa material lempungan hasil pelapukan batulanau kerikilan yang termasuk jenis residual soil [13]. Nilai kecepatan gelombang geser lapisan permukaan di 10 titik ukur mikrotremor array 
selanjutnya diinterpolasi ke seluruh daerah penelitian.

Validasi parameter yang digunakan untuk proses inversi data mikrotremor array dilakukan dengan melakukan pengukuran pada titik ukur yang memiliki data bawah permukaan. Validasi dilakukan di titik bor $\mathrm{DH}-$ 11 di area tapak RDE, dimana di titik tersebut juga dilakukan coring dan tes nSPT (standard penetration test) untuk menilai aspek fisik batuan. Berdasarkan core log, batuan pada tiitk bor DH-11 sudah dapat ditemui pada kedalaman $15 \mathrm{~m}$, akan tetapi pada kedalaman tersebut tes nSPT masih menunjukkan nilai dibawah 50, dimungkinkan pada kedalaman ini secara geologi sudah terdapat batuan tetapi memiliki tingkat kekerasan yang hanya setingkat tanah padat. Oleh karena itu, batuan dasar pada titik bor DH-11 ditentukan berada pada kedalaman $21 \mathrm{~m}$ dengan litologi batulempung. Berdasarkan Pengukuran mikrotremor array di titik DH-11, hasil inversi menunjukkan bahwa batuan dasar ditemukan pada kedalaman 20,38 m dengan kecepatan gelombang geser $467 \mathrm{~m} /$ detik (Gambar 6). Dari perbandingan hasil tersebut, hasil inversi sudah cukup mendekati data bor sehingga parameter model yang digunakan dinilai cukup baik untuk memberikan gambaran kondisi bawah permukaan di daerah penelitian.
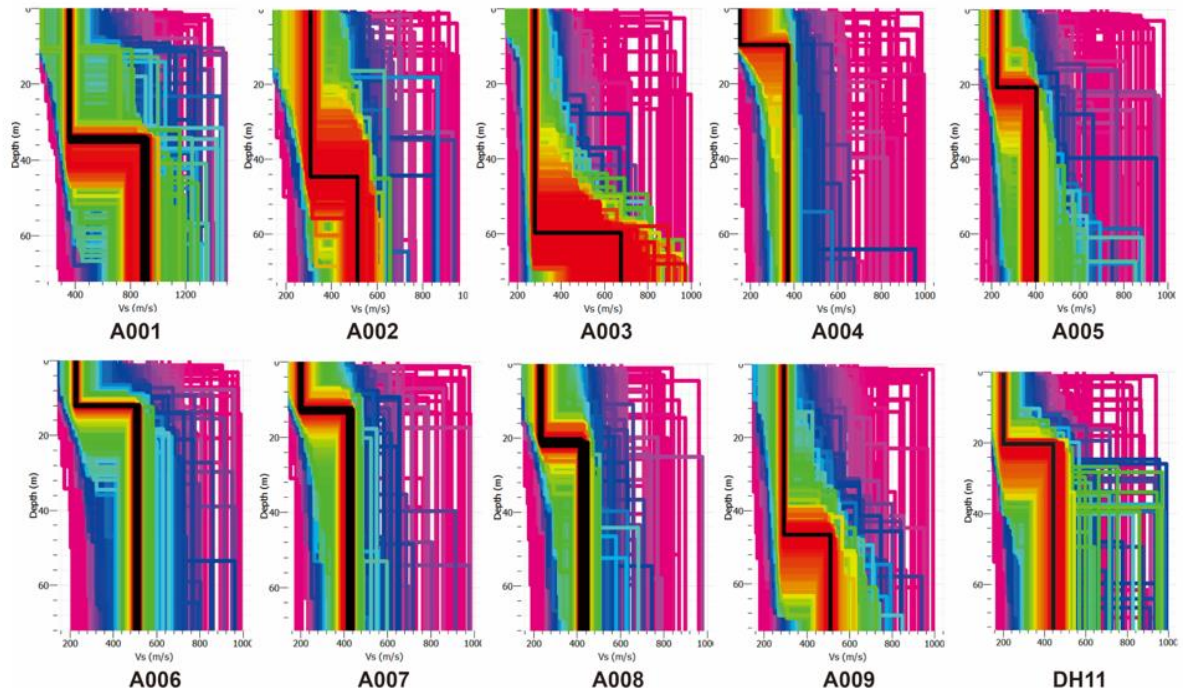

Gambar 5. Model 1D hasil inversi data mikrotremor array di 10 titik ukur.
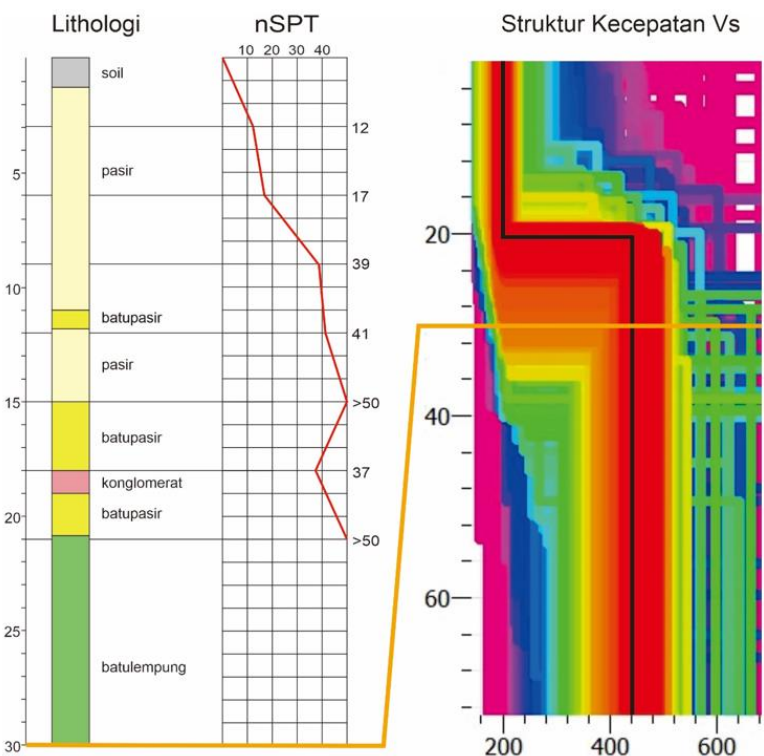

Gambar 6. (a) Data CPT-3 (cone penetrating test) sekitar bor (DH 11) di area tapak RDE Serpong [14] dan (b) hasil inversi data mikrotremor array di lokasi yang berdekatan. 
Nilai kecepatan gelombang sekunder di permukaan, batuan dasar, serta kedalaman dipetakan dengan asumsi topografi yang datar pada setiap titik pengukuran. Secara lateral kecepatan gelombang geser lapisan permukaan menunjukkan nilai relatif tinggi di bagian timur daerah penelitian dan relatif rendah di bagian tengah terutama bagian timur dari Sungai Cisadane (Gambar 7). Berdasarkan Peta Geologi Lembar Jakarta dan Kepulauan Seribu[6], daerah penelitian sebelah timur Sungai Cisadane ini berupa batupasir, batulempung sisipan konglomerat termasuk dalam Formasi Serpong. Adapun di sebelah barat Sungai Cisadane litologi di dominasi oleh batuan pasir tufaan dan batuapung dari Formasi Genteng. Berdasarkan pengamatan langsung di lapangan, bagian permukaan umumnya berupa material lempungan hasil pelapukan dari batuan dasar. Di bagian timur daerah penelitian, memanjang hingga bagian tenggara terdapat anomali kecepatan gelombang geser rendah. Anomali ini kemungkinan berkaitan dengan daerah pengendapan yang paling akhir.

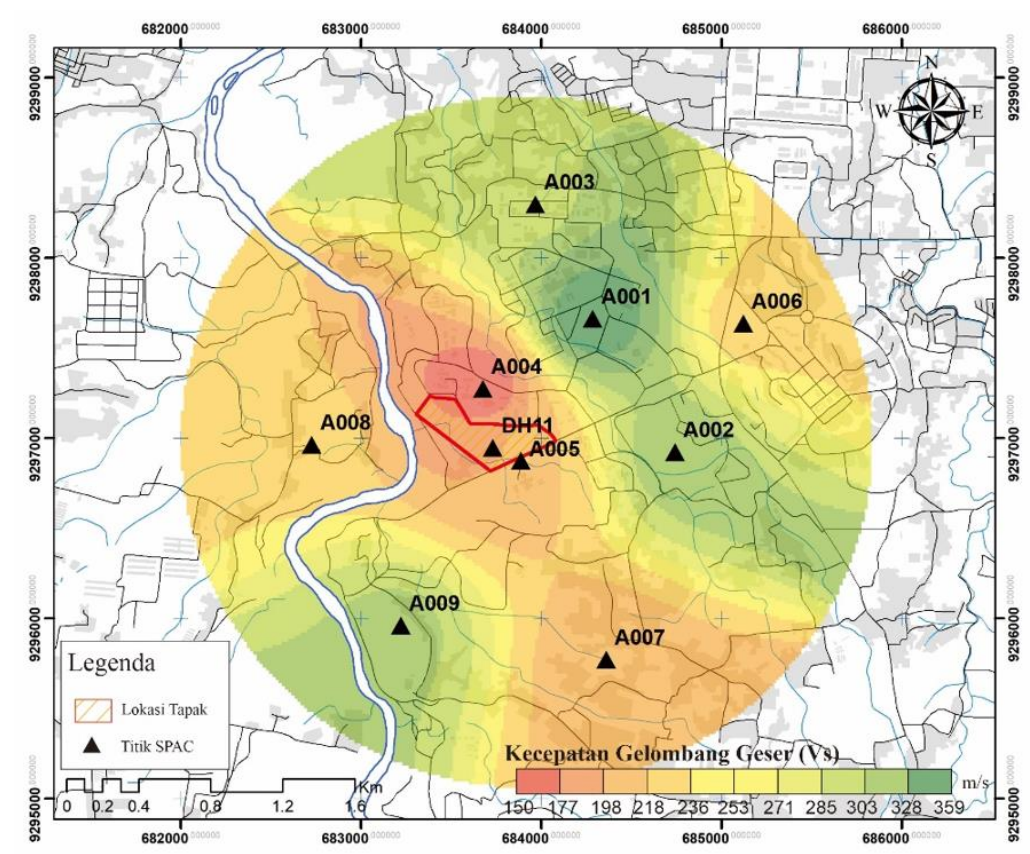

Gambar 7. Sebaran nilai hasil analisis kecepatan gelombang geser lapisan permukaan dalam radius $1 \mathrm{~km}$, daerah tapak RDE, Puspiptek Serpong, Tangerang Selatan.

Lapisan kedua hasil pemodelan memiliki kisaran kecepatan gelombang geser 365 $\mathrm{m} /$ detik sampai $900 \mathrm{~m} /$ detik, diperkirakan merupakan batuan induk dari material lapukan pada lapisan pertama, yaitu batupasir, batulanau kerikilan yang masih segar. Berdasarkan klasifikasi SNI 1726-2012[15], nilai kecepatan gelombang geser lapisan kedua tersebut, termasuk batuan lunak (kelas SC) sampai menengah (kelas SB). Engineering bedrock (Vs $\geq 720 \mathrm{~m} /$ detik) ditemukan pada titik pengukuran A001 dengan nilai Vs hingga $900 \mathrm{~m} /$ detik terdapat pada kedalaman sekitar $34 \mathrm{~m}$. Litologi daerah di sebelah timur Sungai Cisadane ditempati oleh batuan Formasi Serpong yang didominasi oleh batuan konglomerat dengan perselingan batupasir, batulanau, batulempung, konglomerat batuapung dan tuf batuapung. Formasi ini menindih secara tidak selaras di atas Formasi Bojongmanik yang didominasi oleh batupasir gampingan. Berdasarkan pengamatan singkapan batuan Formasi Bojongmanik di pinggiran Sungai Cisadane, secara fisik batupasir gampingan sangat masif. Diperkirakan kedalaman batupasir gampingan di bagian dataran komplek Puspiptek Serpong cukup besar sehingga tidak terjangkau oleh penetrasi pengukuran mikrotremor array.

Kondisi litologi bawah permukaan di sebelah barat Sungai Cisadane tidak banyak informasi, sehingga litologi lapis kedua di daerah ini diperkirakan merupakan batuan Formasi Genteng yang masih segar. Variasi sebaran batuan lapis kedua/batuan dasar secara umum berkecepatan gelombang geser 
tinggi di bagian utara daerah penelitian dan secara gradual menurun ke arah barat (Gambar 8). Sifat fisik yang kemungkinan mempengaruhi pola sebaran ini adalah tingkat pelapukan, perubahan litologi anggota Formasi Serpong sendiri dan kandungan air. Sucipto[14] menyatakan bahwa kondisi morfologi daerah kompleks Puspiptek Serpong termasuk dalam satuan dataran kaki gunung api bergelombang (undulatory volcanic foot slope plain unit) dengan kemiringan antara $0^{\circ}-$ $7^{\circ}$. Dengan kemiringan lereng sebesar nilai tersebut dapat dianggap sebagai dataran, sehingga pemodelan kedalaman batuan dasar dapat diasumsikan dari bidang datar. Hasil perhitungan posisi kedalaman batuan dasar di seluruh daerah penelitian menunjukkan kedalaman berkisar antara $9 \mathrm{~m}$ sampai $60 \mathrm{~m}$.

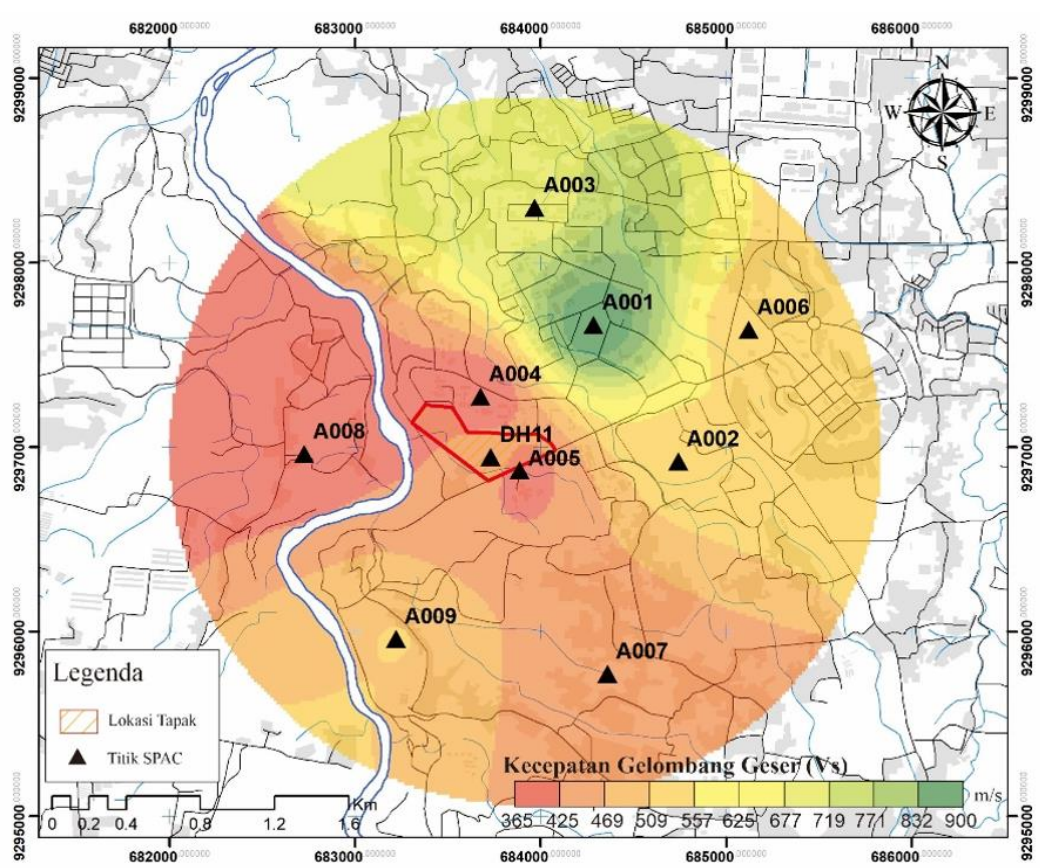

Gambar 8. Sebaran nilai hasil analisis kecepatan gelombang geser batuan dasar dalam radius $1 \mathrm{~km}$, daerah tapak RDE, Puspiptek Serpong,Tangerang Selatan

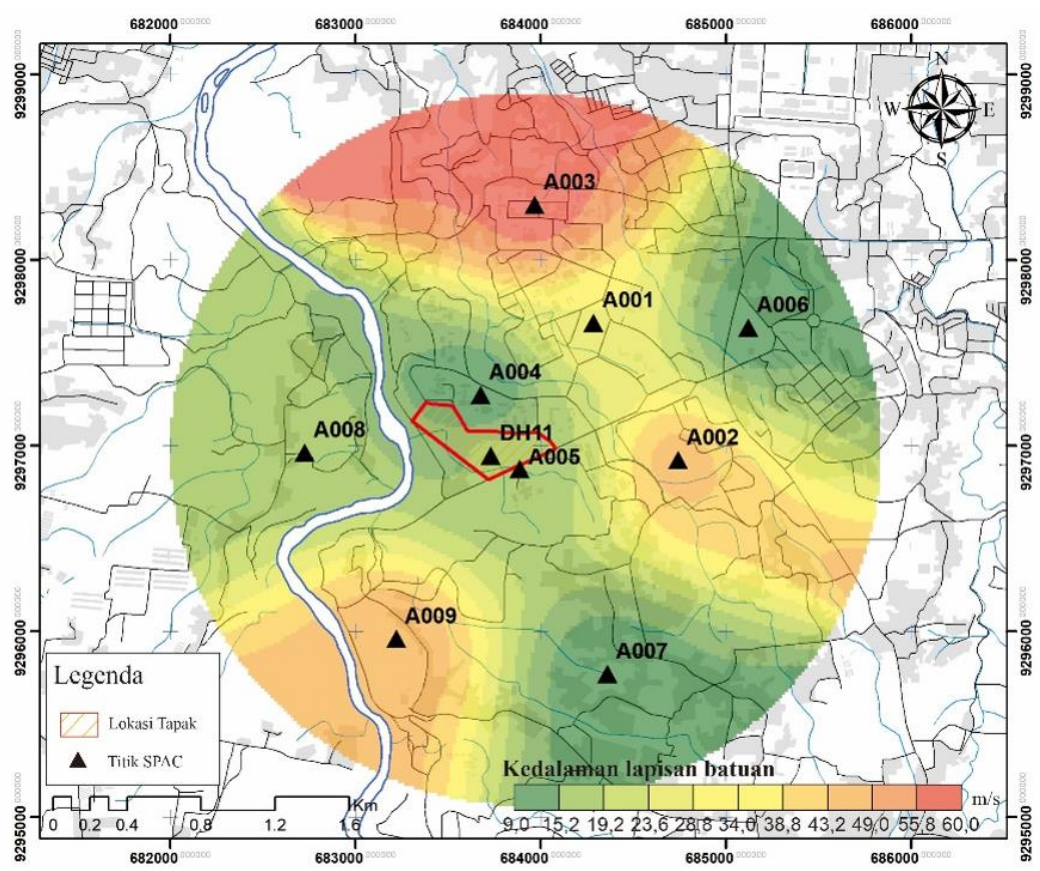

Gambar 9. Peta kedalaman lapisan batuan dasar hasil analisis gelombang geser dalam radius $1 \mathrm{~km}$, daerah tapak RDE, Puspiptek Serpong, Tangerang Selatan. 
Secara umum batuan dasar di bawah permukaan daerah ini relatif datar kecuali di bagian timur terdapat cekungan yang memanjang berarah hampir barat-timur dengan kedalaman mencapai sekitar $60 \mathrm{~m}$ (Gambar 8). Cekungan tersebut terisi oleh material lunak yang ditunjukkan oleh nilai kecepatan gelombang geser rendah (150-190 $\mathrm{m} /$ detik) pada lapisan permukaan (lihat Gambar 7). Bila ditinjau hasil pengamatan di lapangan daerah tersebut secara morfologi merupakan daerah yang relatif rendah, sehingga diperkirakan material pengisi cekungan tersebut merupakan endapan termuda di daerah ini.

Bila ditinjau sebaran nilai kecepatan gelombang geser pada kedalaman batuan dasar (Gambar 8), pada pola cekungan di bagian timur daerah penelitian masih mengikuti pola lapisan endapan permukaan, yaitu menunjukkan pola anomali kecepatan gelombang geser relatif rendah (365-900 $\mathrm{m} /$ detik). Hal ini diduga berkaitan dengan kondisi batuan dasar di daerah ini sudah lapuk karena berada di permukaan sebelum proses pengendapan lapisan permukaan berlangsung. Daerah sekitar rencana tapak reaktor daya eksperimental (RDE) sendiri kondisi batuan dasarnya relatif lunak dengan kecepatan gelombang geser berkisar antara 365-509 $\mathrm{m} /$ detik.

\section{KESIMPULAN}

Berdasarkan konfigurasi kedalaman batuan dasar di daerah penelitian terdeteksi pada kedalaman 9-60m. Secara umum pola kedalaman batuan dasar relatif datar kecuali di bagian timur daerah penelitian teramati adanya pola cekungan yang memanjang berarah hampir barat-timur. Lapisan permukaan merupakan batuan lunak yang dutunjukkan oleh nilai kecepatan gelombang geser yang berkisar antara $150 \mathrm{~m} /$ detik hingga $360 \mathrm{~m} /$ detik di kedalaman $19 \mathrm{~m}$. Daerah sekitar cekungan di bagian timur daerah penelitian ditempati oleh anomali kecepatan geser paling rendah, kemungkinan merupakan endapan termuda di daerah ini. Secara lateral batuan dasar daerah penelitian mempunyai kecepatan gelombang geser berkisar antara $365 \mathrm{~m} /$ detik hingga $900 \mathrm{~m} /$ detik pada kedalaman $60 \mathrm{~m}$ yang dalam klasifikasi SNI 1726-2012 termasuk dalam kelas batuan menengah sampai keras.

\section{UCAPAN TERIMAKASIH}

Terima kasih kami sampaikan kepada Kepala Pusat Kajian Sistem Energi Nuklir, Kepala Pusat Survei Geologi, PSG, Kepala Bidang KDT, PKSEN, BATAN, para peneliti PSG, PKSEN, Bapak Robby Setianegara, Amd. Ssi, dan Bapak Drs. Januar Setiawan, MT, yang telah banyak membantu dalam penyelesaian makalah ini.

\section{DAFTAR PUSTAKA}

[1]. BATAN, "Outlook Energi Nuklir Indonesia 2014", Badan Tenaga Nuklir Nasional, Jakarta, 2014.

[2]. Nakamura Y., "A Method for Dynamic Characteristics Estimation of Subsurface Using Microtremor on the Ground Surface”, Quarterly Report of Railway Technical Research Institute (RTRI), Vol. 30, No.1 ,p25-33, 1989.

[3]. Suntoko dan Sriyana, "Penentuan Kedalaman Batuan Dasar Menggunakan Mikrotremor Array di Tapak RDE Serpong”, Jurnal Pengembangan Energi Nuklir, Vol. 18, No. 2, hal. 87-92, 2016.

[4]. Marjiyono, H. Suntoko, A. Soehaimi, Yuliastuti, and H. Syaeful, "Kelas Soil Daerah Sekitar Rencana Tapak Reaktor Daya Eksperimental (Rde) Serpong Dari Data Mikrotremor," J. Pengemb. Energi Nukl., vol. 17, no. 1, pp. 57-66, 2015, doi: 10.17146/jpen.2015.17.1.2591.

[5]. E. R. Iswanto, H. Suntoko, T. A. Ryanto, and A. Bondan, "PROFIL GELOMBANG GESER AREA REAKTOR DI TAPAK RDE, SERPONG," in Prosiding Seminar Nasional Infrastruktur Energi Nuklir 2019, 2019, pp. 187-194.

[6]. TurkandiT., Sidarto, AgustyantoD.A., dan Hadiwidjojo M.M.,"Peta Geologi Lembar Jakarta dan Kepulauan Seribu, Jawa”, P3G, Bandung, 1992.

[7]. Quispe S., Chimoto K., Yamanaka H., Tavera H., Lazares F. and Aguilar Z., "Estimation of S-Wave Velocity Profiles at Lima City, Peru Using Microtremor Arrays", Journal of Disaster Research, Vol.9 No.6, p931-939, 2014.

[8]. Bouchelouh A., Zaourar N., Farsi M., and Guillier B., "Seismic Microzonation and The Site Effects of Blida City (North of Algeria)", Proceeding of 2nd European on Earth Engineering and Seismology, Istanbul Aug, 25-29, 2014.

[9]. PaudyalY.R., Yatabe R., Bhandary N.P. \& Dahal R.K., " A study of Local Amplification Effect of Soil Layers on Ground Motionin the Kathmandu Valley Using Microtremor Analysis", Earthq. Eng. and Eng. Vib. J., Vol 11, p 257-268, 2012.

[10]. Asten M.W., Askan A., Ekincioglu E.E., Sisman F.N. \&Ugurhan B., " Site Characterization in Northwestern Turkey Based on SPAC and HVSR 
Analysis of Microtremor Noise”, Explor Geophys, Vol 45, p74-85, 2014.

[11]. Ikeda T. AstenM.W. \& Matsuoka T., “ Joint inversion of spatial autocorrelation curves with HVSR for site characterization in Newcastle, Australia”, Proceeding of the 23rd ASEG International Geophysical Conference and Exhibition, Melbourne, Australia, Extended Abstracts, p1-4, 2013.

[12]. Aki K., "Space and Time Spectra of Stationary Stochastic Waves, With Special Reference to Microtremors", Bull. Earthquake Res. Inst. Vol. 35,p415-456, 1957.

[13]. PPGN, "Penyelidikan Geologi Teknik dan Hidrogeologi Tapak Fasilitas Demo Plant PLLR di PPTN Serpong", Laporan Akhir, PTLR, BATAN, 2010.

[14]. BATAN, "Laporan Evaluasi Tapak RDE Kawasan Puspiptek Aspek Kegempaan “, Jakarta 2015

[15]. BSN, "SNI 03 1726-2012 Tata Cara Perencanaan Ketahanaan Gempa untuk Bangunan Gedung", Kementerian Pekerjaan Umum, Jakarta, 2012. 